\title{
Coelacanth population, conservation and fishery activity at Grande Comore, West Indian Ocean
}

\author{
Raphaël Plante $^{1, *}$, Hans Fricke ${ }^{2}$, Karen Hissmann ${ }^{2}$ \\ ${ }^{1}$ Centre d'Océanologie de Marseille, Station Marine d'Endoume, Rue de la Batterie des Lions, F-13007 Marseille, France \\ ${ }^{2}$ Max-Planck-Institut für Verhaltensphysiologie, D-82319 Seewiesen, Germany
}

\begin{abstract}
The only known population of coelacanths, in the Comores, western Indian Ocean, is endangered by human predation. Historical catch data from Grande Comore reveal that annual catch rates increased steadily from 1954 until the 1970 s. This trend was temporarily interrupted due to an international policy introducing motorized boats and promoting offshore fishing techniques. Coelacanths are only caught from traditional unmotorized outrigger canoes as an incidental by-catch of deep water line fishing. A complete survey of all motorized and unmotorized vessels in 1995 at Grande Comore in comparison to earlier years indicated that a recent decreased use of motors and increase of unmotorized canoe fishing has led to an increase in coelacanth catches. Conservation measures and strategies for reducing the fishing pressure exerted on coelacanths are discussed. The southwest coast of Grande Comore should be designated as a nature reserve and protected area where immediate protection measures should be taken, an opinion which is supported by Comorian authorities.
\end{abstract}

KEY WORDS: Coelacanth · Latimeria $\cdot$ Comoro Islands · Conservation measurements

\section{INTRODUCTION}

The threatened survival of the only living actinistian fish, Latimeria chalumnae, has raised worldwide attention (Balon et al. 1988, Fricke et al. 1995). The fish is of high scientific, educational and, increasingly, economic value (Forey 1988). It inhabits the steep slopes of the volcanic islands Grande Comore and Anjouan (western Indian Ocean) at depths between 150 and $700 \mathrm{~m}$. The coelacanth is a rare fish, and first estimations of the population size at Grande Comore were made of less than 500 to 600 individuals, although there are now likely to be less than 200: between 1991 and 1994 a $30 \%$ population decrease was recorded (Hissmann et al. 1998), and recent fishery developments are likely candidates as the cause of this decline (Fricke et al. 1995).

Coelacanths are caught exclusively by native fishermen as incidental by-products of the oilfish (Ruvettus pretiosus) fishery using traditional unmotorized outrigger canoes (locally called 'galawa') from which they

·E-mail: plante@com.univ-mrs.fr are hooked with deep water lines close to the shore at depths down to $800 \mathrm{~m}$ (Millot et al. 1972, Stobbs \& Bruton 1991). Thus the number of operational seagoing galawas can be taken as a first estimate of fishing pressure exerted on the coelacanth. In contrast, motorized canoes and boats fish mainly offshore outside the coelacanth's realm and thus do not threaten the fish. There is only one record of a coelacanth landed from a motorized boat (Bruton \& Coutouvidis 1991)

As part of growing international concern and initiative, we studied the possible impact of the artisanal fishery on the coelacanth population. We recorded the distribution of motorized ('non-coelacanth predator') and unmotorized boats ('coelacanth predator') and analyzed coelacanth catches in the past and present. The analysis should assist in establishing a protective area and in making recommendations for further conservation measures.

\section{METHODS}

In November 1991 canoes and boats were counted at 9 villages along the west coast of Grande Comore. In 
November 1995 counts were repeated with the help of local investigators, and extended to all fishing villages to obtain the complete distribution of canoes and boats at Grande Comore. Fishing techniques are identical along the entire coastline (Stobbs \& Bruton 1991). In our analyses, we have assumed that the average fishing effort performed from galawas does not vary between villages along the coast, an assumption confirmed by interviews of fishermen and our own observations. All galawa fishermen fish with the same fishing gear and within the same range.

The number of traditional outrigger canoes was obtained by counting both actively fishing galawas in nearshore waters and those pulled up onto the beaches. Similar counts were made of motorized canoes and boats. These are used mainly for trawling and offshore fishing and were introduced to the Comores in the mid 1980s. Three different larger boats of varying sizes, engines and crew exist (japawa, fedawa, vedette); they were classified, together with galawas fitted with outboard engines, as motorized. Only those canoes and boats in operational seagoing condition were counted, while those under construction or repair were excluded.

The coastline was divided into 5 sectors in order to investigate and compare the distribution of all types of canoes and boats in relation to local coelacanth catches. Sectors differ in size because topographical and geological features, and the results of an earlier echoprofile survey (Fricke \& Plante 1988), were used

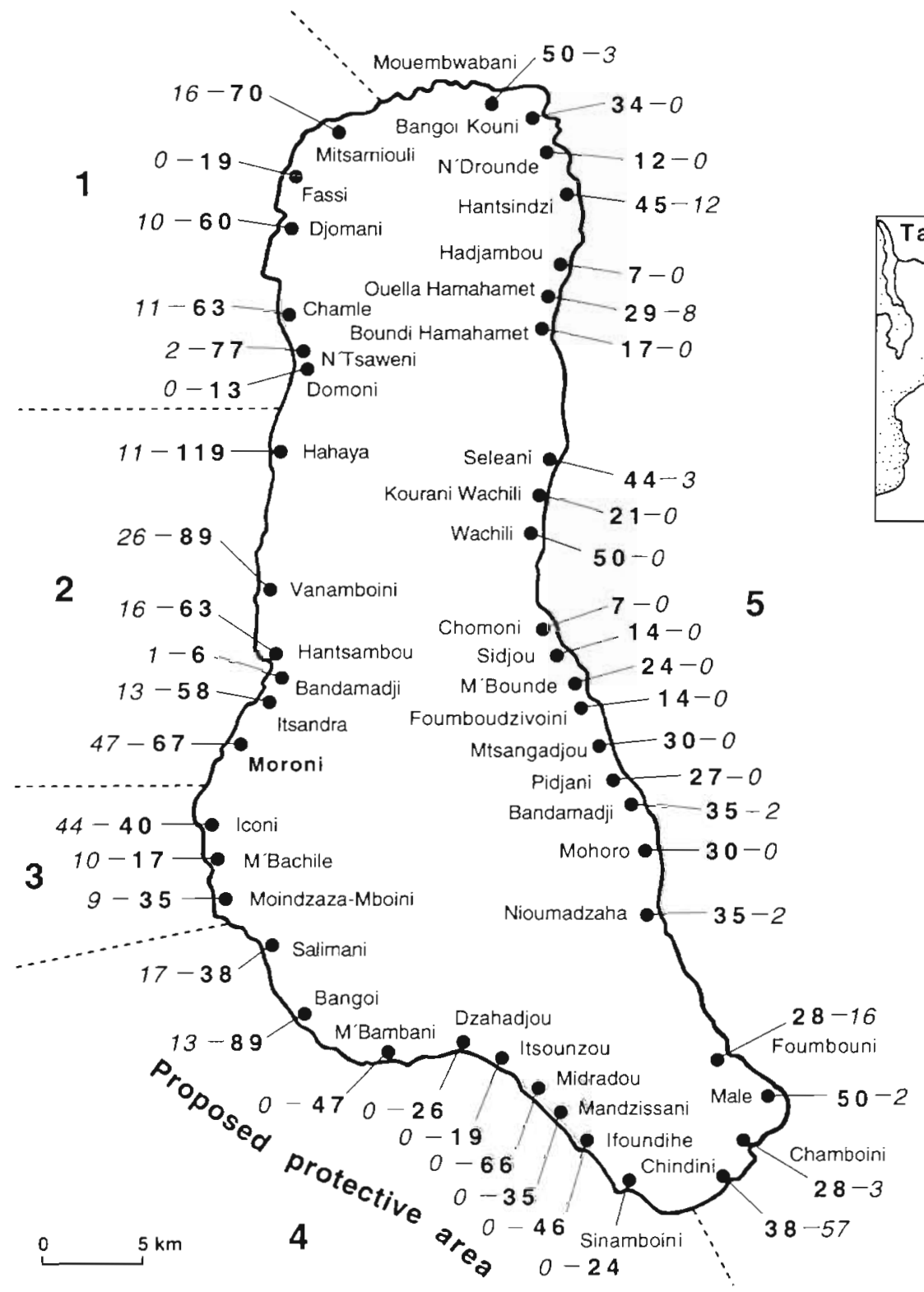

Fig. 1. Designation of survey sectors and distribution of motorized (outer number) and unmotorized (inner number) canoes in fishing villages on Grande Comore in November 1995, with indication of proposed coelacanth reserve 
for their designation. Each sector encompasses bottoms of the same type, is exposed to similar oceanographic conditions and contains villages with similarly developed fisherman populations.

Interviews, using a standardized protacol, were conducted with fishermen of all visited fishing villages in order to estimate the number of coelacanth catches during the last 6 yr (accurate catch statistics on the coelacanth are not being kept in the Comores). All interviews were performed in the same time interval, from 11:00 to 16:00 h, when most fishermen gather in the 'fishermen's house' after fishing hours, and their canoes are landed on the beach. Questions were asked in a consistent and unbiased order. To compare the catch numbers with catch rates of former years, published accounts by Millot et al. (1972; 1954 to 1971), C.N.D.R.S. Moroni (Centre National de Documentation et de Recherche Scientific; recent years), Stobbs \& Bruton (1991; 1972 to 1989) and the comprehensive inventory of Bruton \& Coutouvidis (1991) were used. The interviews supplied additional anecdotal knowledge about fishing practices and information on the whereabouts of caught specimens (e.g. storage in hotels, private or official deep freezers; black market practices; number of released or killed specimens).

\section{RESULTS}

\section{Distribution of fishing villages and boats}

The fishing villages were almost equally distributed around the island, and in each sector coast length correlates with number of fishing villages $\left(r_{\mathrm{s}}=1, \mathrm{p}=0.01\right.$; Fig. 1).

In 1995 we counted a total of 2209 canoes and boats, of which $16 \%$ were motorized and $84 \%$ unmotorized (Table 1). A strong asymmetry in proportion of motorized and unmotorized boats exists between different sectors. Sector 3 with the prosperous fishing villages Iconi and $M^{\prime} B$ achile has a ratio of $1: 1.5$, while sector 4 with a series of poor villages has a ratio of $1: 13.0$. Most villages in sector 4 possess no motorized boats (M'Bambani to Sinamboini). In 2 wealthy communities (Iconi and Chindini) motorized boats outnumbered the unmotorized galawas (Fig. 1).

In 1991 we began investigating the proportion of motorized to unmotorized canoes and boats at 9 villages on the west coast (Mitsamiouli, Djomani, N'Tsaweni, Hahaya, Vanamboini, Hantsambou, Moroni, Iconi, M'Bachile). They were respectively 181 and 465. When repeating the counts at the same locations in 1995, they were respectively 153 and 550. The
Table 1. Numbers of motorized and unmotorized canoes at Grande Comore in November 1995 in different sectors of the island (see Fig. 1)

\begin{tabular}{|lccl|}
\hline Sector & Motorized & Unmotorized & Ratio \\
\hline 1 & 39 & 302 & $1: 7.7$ \\
2 & 114 & 402 & $1: 3.5$ \\
3 & 63 & 92 & $1: 1.5$ \\
4 & 30 & 390 & $1: 13.0$ \\
5 & 108 & 669 & $1: 6.2$ \\
Total & 354 & 1855 & \\
\hline
\end{tabular}

distribution of both types changed significantly over this 4 yr period with more galawas and fewer motorized boats in $1995\left(\chi^{2}=7.07, \mathrm{df}=1, \mathrm{p}=0.0078\right)$.

\section{Coelacanth catches between 1954 and 1995}

Since 1954, a total of 120 coelacanth catches have been reported from Grande Comore, and, of these, 101 reports included the precise location of landing (Bruton \& Coutouvidis 1991). Annual catch data varied considerably (Fig. 2) so that a regression analysis for the entire period revealed no significant trend ( $F$-test, $r=0.17$, ns). However, number of catches did increase significantly from 1986 to 1995 (F-test, $r=0.67, \mathrm{p}<$ 0.048 ). The average number of coelacanths caught per year increased from the 1950 s to the 1970 s, decreased in the 1980 s and then increased again during the last 6 yr (Table 2).

Table 2 shows the distribution of catches in different sectors from 1954 to 1995. Most specimens were caught in sectors 2, 3 and 4, while sectors 1 and 5 are areas with low numbers of coelacanth catches. In both sectors 1 and 5, no specimens were caught after 1989. In sector 3 catches increased until 1979, and decreased

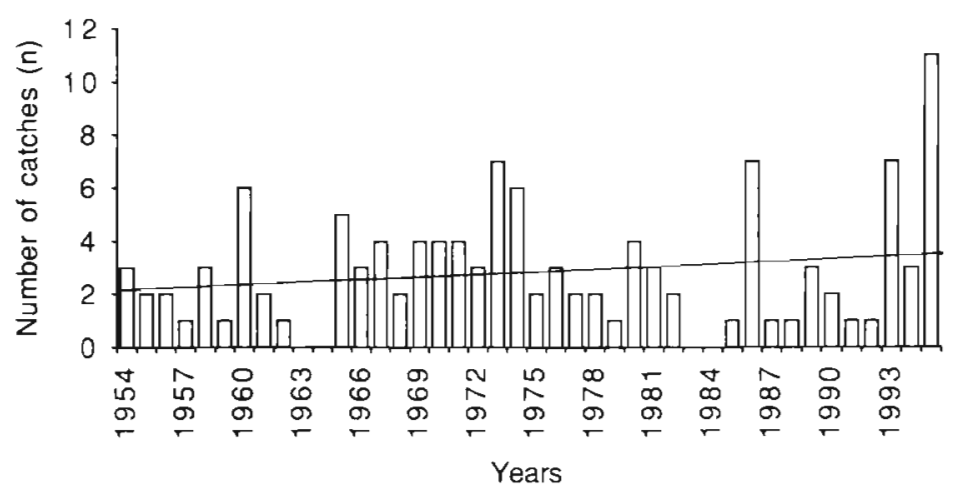

Fig. 2. Number of coelacanth catches per year at Grande Comore from 1954 to 1995 . The regression line shows an increasing but statistically not significant trend 
Table 2. Number of coelacanths caught between 1954 and 1995 in different sectors of Grande Comore (see Fig. 1) as well as those of unknown origin. Standard deviations of average number of catches per year are calculated from data presented in Fig. 2

\begin{tabular}{|lcccccc|}
\hline Sector & $1954-59$ & $1960-69$ & $1970-79$ & $1980-89$ & $1990-95$ & Total (n) \\
\hline 1 & 0 & 3 & 0 & 1 & 0 & 4 \\
2 & 2 & 7 & 4 & 2 & 6 & 21 \\
3 & 3 & 8 & 19 & 4 & 2 & 36 \\
4 & 5 & 6 & 7 & 6 & 14 & 38 \\
5 & 0 & 1 & 0 & 1 & 0 & 2 \\
Unknown & 2 & 2 & 4 & 8 & 3 & 19 \\
Total & 12 & 27 & 34 & 22 & 25 & 120 \\
Average & & & & & & \\
per year & 2 & 2.7 & 3.4 & 2.2 & 4.2 & \\
(SD) & $(0.9)$ & $(2.1)$ & $(1.9)$ & $(2.2)$ & $(4.0)$ & \\
\hline
\end{tabular}

are used all around the island, whereas motorized fishing crafts are restricted to relatively prosperous fishing villages. Fishermen using simple traditional canoes are the poorest members of their community, with low social status. Traditional canoes are found along both coastlines. During the last 6 yr, no coelacanth has been caught along the east coast; all catches occurred along the west coast, which confirms our earlier findings (Fricke \& Plante 1988, Fricke et al. 1991). The restricted abundance was explained by differences in geomorphological structures between both coasts: the west coast is geologically younger, steeper and more structured than the older, more strongly eroded east coast. Since there are no differences in fishing techniques and activities between the

drastically afterwards. In sector 4 numbers were stable until 1989, but doubled during the last $6 \mathrm{yr} ; 56 \%$ of all catches between 1990 and 1995 occurred in sector 4 .

If fishing effort from galawas is the same everywhere, more coelacanths are expected to be caught by a similar number of galawas in areas of higher coelacanth abundances than in areas with low fish density. Table 3 shows the number of coelacanth catches per 100 galawas between 1990 and 1995 in each sector. The ratio increases from north to south along the west coast (0 to 3.1$)$. Sectors 2 and 4 have similar numbers of galawas (see Table 1), but sector 4 has more catches than sector 2 (see Table 2) indicating a higher coelacanth density in this sector. This is also confirmed by our visual observations from on board our submersibles GEO and JAGO, carried out between 1987 and 1995 around the entire island.

\section{DISCUSSION}

\section{Fishery developments and the impact of human predation}

Although coelacanths are only caught as incidental by-products of the oilfish fishery, and no specialized coelacanth fishery exists (Stobbs \& Bruton 1991), we assume that human predation pressure is mainly exerted from the traditional artisanal fishery. Modern motorized boats fish outside of the coelacanth realm and thus are not expected to harm the population. Therefore a complete survey of the traditional canoes and motorized boats is so far the best possible way to estimate the threat to the coelacanth population.

The complete survey of numbers of fishing canoes and boats at Grande Comore revealed that galawas coasts, the entire coelacanth population at Grande Comore seems to be restricted to the west coast of the island.

The introduction of motorized fishing craft in the mid 1980 s did not change the asymmetry of coelacanth catches, but probably had an influence on the annual catch rates. Motorized canoes are used mostly for trolling pelagic fish offshore in the Mozambique Channel, particularly those which aggregate around Fish Aggregating Devices (FADs) moored in very deep water outside the coelacanth habitat. FADs are arrays of floating buoys and plastic ribbons under which pelagic fishes gather. They were installed off the Comorian coast in the late 1980 s by the Fonds Européen de Développment (FED) (de San \& Rotsaert 1991). Coelacanths were always caught nearshore with traditional paddle canoes, and thus one should expect that the fishing pressure exerted on coelacanth populations would decrease as motorization gradually replaced traditional canoes. The catch records of the last 40 yr reflect these developments. Although there are no reliable records on numbers of traditional canoes before 1980, the artisanal nearshore fishery increased with the quickly growing human population

Table 3. Number of coelacanths caught in different sectors in relation to number of traditional canoes (galawas), normalized to 100 galawas

\begin{tabular}{|lc|}
\hline Sector & Catches per 100 galawas \\
\hline 1 & 0 \\
2 & 1.7 \\
3 & 2.4 \\
4 & 3.1 \\
5 & 0 \\
\hline
\end{tabular}


and the concomitant demand for marine proteins. Consequently, the coelacanth catch rate rose continuously until the 1980 s (Table 2). The subsequent introduction of motorized fishing boats and the growing offshore fishery led to a distinct decrease of coelacanth catches between 1986 and 1991. This is well demonstrated in the coelacanth catch records for Iconi, one of the wealthiest and most active fishing villages on Grande Comore. Millot et al. (1972) reported that most coelacanths were caught here, whereas only 2 specimens were caught by fishermen from Iconi between 1986 and 1995, probably due to motorization and the change from more inshore to offshore fishery.

Iconi, however, is unfortunately an exception among the fishing villages. Since 1991 the annual catch rate at Grande Comore has risen again, and this is reflected in the shifted ratio of motorized to unmotorized boats. The number of galawas increased between 1991 and 1995 while the number of motorized boats decreased, and this is mainly due to the lack of mechanical workshops and spare parts in the villages. A survey by the FED carried out in the late 1980 s listed 423 motorized boats at Grande Comore (de San \& Rotsaert 1991), of which we found only 354. In 1995, at Vanamboini, one of the main fishing villages along the west coast, $40 \%$ of the outboard engines were lying in disrepair on the shore, and thus many fishermen in sector 2 have most probably recently returned to traditional nearshore fishing methods. The recent increase in the coelacanth catch rate is probably a direct consequence of this development. Many fishermen complain about overfishing of their inshore waters, and as a result they are presently forced to go for deep water resources (100 to $400 \mathrm{~m}$ ). According to telemetry studies, the activity range of coelacanths is located between 150 and $700 \mathrm{~m}$ (Fricke \& Hissmann 1994). Thus an increase of deep line angling increases the chances of hooking coelacanths

More than half of all coelacanth catches between 1990 and 1995 occurred in sector 4, an extremely poor sector where mainly outrigger canoes are used. During our last submersible survey of this sector in 1994, we recorded a reduction of $30 \%$ in sighted coelacanths compared to 1991 (Hissmann et al. 1998). We fear that the observed decline is due to the intensified traditional fishing efforts with an increasing number of galawas.

\section{Recommendations for conservation actions}

Our submersible surveys and the catch records in sector 4 indicate that the southwestern shores have the highest coelacanth density at Grande Comore. During the last 6 yr no coelacanths where caught in sectors 1 and 5 although the traditional fishing activities were similar to those in sector 4 . The actual occurrence of coelacanths at Grande Comore may be restricted to sectors 2, 3 and 4: a total area encompassing $60 \mathrm{~km}$ of coastline. We therefore propose a protective area in sector 4 between Salimani and Sinamboini where all future conservation actions should be directed.

Our data are based on inquiries only; the increase of the annual coelacanth catch rate during recent years may be even higher than reported. Latimeria was included in Appendix I of the Convention on International Trade in Endangered Species of Wild Fauna and Flora (CITES) in 1989 and the Comorian Government signed the CITES Convention in 1994. The capture of coelacanths is now officially prohibited, although it was known that coelacanths cannot be captured on demand and were always caught by accident. This situation has the effect that fishermen hesitate to declare their catches. Coelacanths have also been killed at sea in order to retrieve the hook and released afterwards into the water to avoid governmental problems. But there is also a growing environmental concern among the fishermen population. Two cases are reported of coelacanths being purposely released after surfacing; it is not known if they survived the stress of capture.

The survival of the world's only living coelacanth species seems to be severely threatened. In the past a variety of conservation measures for the coelacanth were proposed (Bruton \& Stobbs 1991). However, no constructive conservation program has been realized so far. If the increase of human predation is indeed the main cause for the decline and the catch rate continues to rise, conservation efforts should mainly focus on reducing the fishing pressure exerted on coelacanths. This is required in particular for the southwestern shores of Grande Comore.

Since the human population of Grande Comore depends on its fishery, it is not possible to prohibit fishing in areas with high coelacanth densities. Besides the improvement of the offshore fishery, international development programs should help to build up nearshore alternatives for traditional deep water angling.

According to investigations made by the FED program, Fish Aggregating Devices (FADs) installed nearshore along open oceanic islands have efficiency similar to those moored offshore. Nearshore FADs can easily be reached by paddle canoes. Preyfish aggregating in nearshore FADs are only caught in shallow surface water. Therefore FADs would relieve the fishing pressure on the coelacanths and the population would be less threatened by an increasing inshore fishery. These proposals and points of view are also expressed by Comorian authorities and representatives (e.g. M. Allaoui, Director of C.N.D.R.S., pers. comm.). 
Acknowledgements. This study was funded by grants to H.F. by the German Research Council (DFG-Project Fr 369/10-2 to 10-4 and 14-1), the Max Planck Society, the Frankfurt Zoological Society - Help for the Threatened Wildife (ZFG 10 26/87 and ZGF $1036 / 87$ ), and the Fondation Nicolas Hulot pour la Nature et l'Homme (France). The Conseil Régional PACA covered travel expenses. In Moroni we thank the C.N.D.R.S particularly $\mathrm{M}$. Allaoui for organizing the inquiries, M. Ali, M. Fouad, Y. Ali, P. Bonhomme and S. Ahamada for field assistance, and the French Mission de Cooperation as well as F. Abdallah and I. Valade of the Fonds Européen de Développement for much logistical assistance. T. Sharbel kindly improved the English text.

\section{LITERATURE CITED}

Balon EK, Bruton MN, Fricke HW (1988) A fiftieth anniversary reflection on the living coelacanth, Latimeria chalumnae: some new interpretations of its natural history and conservation status. Environ Biol Fish 23:241-281

Bruton MN, Coutouvidis SE (1991) An inventory of all known specimens of the coelacanth Latimeria chalumnae, with comments on trends in the catch. Environ Biol Fish 32: $371-390$

Bruton MN, Stobbs RE (1991) The ecology and conservation of the coelacanth Latimeria chalumnae. Environ Biol Fish $32: 313-339$

Editorial responsibility: Otto Kinne (Editor), Oldendorf/Luhe, Germany de San M, Rotsaert E (1991) Rapport de fin de la premier phase du project du 1er Septembre 1987 au 30 juin 1991. Project FED No 5100.36.01.048, European Development Fund, European Economic Community, Brussels, p 7

Forey PL (1988) Golden jubilee for the coelacanth Latimena chalumnae. Nature 336:727-732

Fricke HW, Hissmann K (1994) Home range and migrations of the coelacanth Latimeria chalumnae. Mar Biol 120:171-180

Fricke HW, Hissmann K, Schauer J, Plante R (1995) Yet more danger for coelacanths. Nature 374:314

Fricke HW, Hissmann K, Schauer J, Reinicke O. Kasang L, Plante R (1991) Habitat and population size of the living coelacarth Latimeria chalumnae. Environ Biol Fish 32: $287-300$

Fricke HW, Plante R (1988) Habitat requirements of the living coelacanth Latimeria chalumnae at Grande Comore, Indian Ocean. Naturwissenschaften 75:149-151

Hissmann K. Fricke H, Schauer J (1998) Population monitoring of the coelacanth Latimeria chalumnae. Conserv Biol (in press)

Millot J, Anthony J, Robineau D (1972) Etat commenté des captures de Latimeria chalumnae Smith (Poisson, Crossoptérygien, Coelacanthıdel effectuées jusqu'au mois d'octobre 1971. Bull Mus Nat Hist Nat Paris (Sér 3 Zool) 39:533-548

Stobbs RE, Bruton MN (1991) The fishery of the Comores, with comments on its possible impact on coelacanth survival. Environ Bıol Fish 32:34i-359

Submitted: September 3, 1997; Accepted: April 3, 1998 Proofs received from author(s): April 30, 1998 